\title{
Improvement of water-air properties of eroded soils in a loess landscape after the application of agrohydrogel*
}

\author{
JAN PALUSZEK, WOJCIECH ŻEMBROWSKI \\ Institute of Soil Science and Environment Management, University of Life Sciences
}

\begin{abstract}
Improvement of water-air properties of eroded soils in a loess landscape after the application of agrohydrogel. The research was carried out in a field experiment in eroded Haplic Luvisols developed from loess at a privately owned farm in Bogucin $\left(51^{\circ} 20^{\prime} \mathrm{N}, 22^{\circ} 23^{\prime} \mathrm{E}\right)$ at the Lublin Upland. After spring wheat had been sawn, 9 plots with an area of $9 \mathrm{~m}^{2}$ each, including 3 control plots, were marked out. AgroHydroGel was spread over in the doses of $1 \mathrm{~g} \cdot \mathrm{kg}^{-1}$ and $2 \mathrm{~g} \cdot \mathrm{kg}^{-1}$ (recalculated to dry soil) and mixed within the $0-5 \mathrm{~cm}$ layer of soil. AgroHydroGel is a cross-linked hydrophilic polyacrylamide copolymer with water absorption of $300-500 \mathrm{~g} \cdot \mathrm{cm}^{-3}$. Soil samples were collected in June and August 2005 at the layer of $0-5 \mathrm{~cm}$. The results of this study indicate that the use of AgroHydroGel in the doses of 1 and $2 \mathrm{~g} \cdot \mathrm{kg}^{-1}$ improved the majority of the water-air properties in the soil surface layer. The bulk density decreased significantly whereas the maximum water capacity, saturated hydraulic conductivity, total porosity, content of macropores $>20 \mu \mathrm{m}$, actual air permeability and permeability at field water saturation were significantly higher. The polymer dose of $2 \mathrm{~g} \cdot \mathrm{kg}^{-1}$ was more effective, increasing significantly also field water capacity in the soils studied. The applied doses of the hydrogel did not change significantly actual soil moisture, retention of water useful to plants, including retention of easily available water, and content of water-stable aggregates $<0.2 \mu \mathrm{m}$ in diameter. A more beneficial effect of AgroHydroGel on water-air properties of the eroded soils was found in August.
\end{abstract}

\footnotetext{
* The study funded from research resources in 2007-2008 as the research project N N310 377033.
}

Key words: Haplic Luvisols, eroded soils, AgroHydroGel, water properties, air properties.

\section{INTRODUCTION}

In a loess landscape, accelerated soil erosion by water results in shortening of soil pedons and deterioration of soil properties. In comparison to non-eroded soils, eroded soils, whose Ap horizons developed from an illuvial horizon, contain more clods $>10 \mathrm{~mm}$ in their aggregate size distribution, have lower water stability of aggregates, higher density, lower retention of water useful to plants, air capacity and air permeability (Ebeid et al. 1995; Lowery et al. 1995; Lal 1998; Shukla and Lal 2005). An unstable aggregate structure contributes to surface crust forming and further water erosion during heavy run-off periods. Besides, cultivated plant crops from eroded soils are poorer. As potentially rich in nutrients for plants, those soils require restoration of a stable aggregate structure and improvement of water and air properties. Traditional methods for improving soil physical properties include fertilization with high doses of organic fertilizers, the application of $\mathrm{N}-\mathrm{P}-\mathrm{K}$ fertilizers, liming, and crop rota- 
tion with greater use of papilionaceous plants and grasses (Hussain et al. 1998; Dabney et al. 2001; Arriaga and Lowery 2003). The traditional methods may be supplemented by adding synthetic gel-forming polymers to soil, resistant to microbiological decay, non-toxic and environmentally safe. (Al-Darby 1996; Akhter et al. 2004; Geesing and Schmidhalter 2004; Sivapalan 2006).

The purpose of the study was to evaluate potential improvement of water and air properties of the surface layer of Haplic Luvisols developed from loess with varying classes of erosion, resulted from the application of small doses of the polymer AgroHydroGel.

\section{MATERIAL AND METHODS}

The research was carried out at a privately owned farm in Bogucin $\left(51^{\circ} 20^{\prime} \mathrm{N}\right.$, $22^{\circ} 23^{\prime} \mathrm{E}$ ) at the Lubelska Upland, in a field experiment established in 2005 . The experiment was located on a slope with inclination ranging from 11 to $15 \%$, transversal to the direction of the tillage. The following Haplic Luvisols developed from loess were selected for the study: the slightly eroded soil with the sequence of genetic horizons Ap-Btl-Bt2-BC-Ck, moderately eroded soil with the sequence of genetic horizons Ap-Bt2-BC-Ck, and strongly eroded soil with the sequence of genetic horizons Ap-BC-Ck.

In 2005, sugar beet (Beta saccharifera) was replaced by spring wheat (Triticum aestivum L.) (variety Nawra). Cultivation management included winter ploughing, cultivatoring and harrowing in spring. The mineral fertilization per hectare was as follows: $40 \mathrm{~kg}$ of N (once, full dose before sowing), $23 \mathrm{~kg}$ of $\mathrm{P}$, and $75 \mathrm{~kg}$ of $\mathrm{K}$. In the beginning of April 2005, after spring wheat had been sown and post-sowing harrowing had been carried out, 3 plots with an area of $9 \mathrm{~m}^{2}$ each, including 1 control plot, were marked out on every soil. As a supplementary agrotechnical treatment, AgroHydroGel was introduced into the soil. It was spread over in the doses of $1 \mathrm{~g} \cdot \mathrm{kg}^{-1}$ and $2 \mathrm{~g} \cdot \mathrm{kg}^{-1}\left(550 \mathrm{~kg} \cdot \mathrm{ha}^{-1}\right.$ and $1100 \mathrm{~kg} \cdot \mathrm{ha}^{-1}$, respectively recalculated to dry soil) and afterwards mixed within the $0-5 \mathrm{~cm}$ layer of soil. AgroHydroGel (made by Agroidea) is a cross-linked hydrophilic polyacrylamide copolymer whose dried macronets take the form of crystalline white grains with diameter of $0.1-4 \mathrm{~mm}$ and with the water-absorption ability of $300-500 \mathrm{~g} \cdot \mathrm{cm}^{-3}$. The soil samples with undisturbed structure were collected in four replications to metal cylinders with the volume of $100 \mathrm{~cm}^{3}$ at the layer of 0-5 cm on 14 June and 8 August 2005.

Specific gravity of the soils was determined using the pycnometric method. Bulk density was calculated from the ratio of a mass of the soil dried at $105^{\circ} \mathrm{C}$ to its volume. Actual soil moisture during sampling was measured by the gravimetric method. Water capacity measured in the range of soil water potential from $0.1 \mathrm{kPa}$ to $-1554 \mathrm{kPa}$ was determined in pressure chambers, on porous ceramic plates (made by Soil Moisture Equipment Corporation). Retention of water useful to plants (within the range of the potential from -15.5 to $-1554 \mathrm{kPa}$ ), including retention of easily available water (from -15.5 to $-155.4 \mathrm{kPa}$ ) and poorly available water (from -155.4 to $-1554 \mathrm{kPa}$ ) was calculated as a difference of water capacity values corresponding to the 
potential. Saturated hydraulic conductivity was determined with the use of Wit apparatus (made by Eijkelkamp) calculating filtration coefficient. Total porosity was calculated on the basis of values of specific gravity and bulk density. Contents of soil pores with diameters of $>20 \mu \mathrm{m}, 0.2-20 \mu \mathrm{m}$ and $<0.2$ were calculated on the basis of water capacity values expressed in $\mathrm{m}^{3} \cdot \mathrm{m}^{-3}$. Air permeability was measured using LPiR apparatus (made by Polish Foundry Research Institute in Cracow) for measurement of air permeability in the sandmix. Texture was determined according to Bouyoucos method with Casagrande and Prószyński modifications, separating the sand fraction in the range of $0.1-1.0 \mathrm{~mm}$ on a $0.1 \mathrm{~mm}$ sieve. $\mathrm{C}_{\text {org }}$ content was determined according to Tiurin's method modified by Simakov, and soil reaction in $1 \mathrm{~mol} \mathrm{KCl}$ $\mathrm{dm}^{-3}$ potentiometrically using a combination electrode.

The data were subjected to analysis of variance (ANOVA) for two-way classification in the completely randomised design. The significance of the differences obtained was verified by Tukey's test.

\section{RESULTS AND DISCUSSION}

The Ap horizons of the Haplic Luvisols studied comprised of: $0.4-0.6 \%$ of the $1.0-0.1 \mathrm{~mm}$ fraction, $57.4-59.6 \%$ of the $0.10-0.02 \mathrm{~mm}$ fraction, and $40-42 \%$ of the $<0.02 \mathrm{~mm}$ fraction, including $15-17 \%$ of the $<0.002 \mathrm{~mm}$ clay. The total organic carbon content varied from $10.32 \mathrm{~g} \cdot \mathrm{kg}^{-1}$ in the slightly eroded soil to $7.27 \mathrm{~g} \cdot \mathrm{kg}^{-1}$ in the strongly eroded soil, and the soil weak-acid reaction ranged from 5.8 to $6.1 \mathrm{pH}$. The specific gravity of the soils was within the range of $2.64-2.65 \mathrm{Mg} \cdot \mathrm{m}^{-3}$.
In the plots where AgroHydroGel was added, the bulk density in the $0-5 \mathrm{~cm}$ layer was significantly lower by 0.08 $-0.11 \mathrm{Mg} \cdot \mathrm{m}^{-3}$ than in the control (Tab. 1). Actual soil moisture during sampling depended chiefly on the collecting date and its values were significantly higher (by $0.036 \mathrm{~kg} \cdot \mathrm{kg}^{-1}$ on average) in June than in August. Moisture differences caused by hydrogel inputs were insignificant, though.

The application of AgroHydroGel significantly elevated the maximum water capacity of the soils (at the soil water potential of $-0.1 \mathrm{kPa}$ ) by 0.050 $-0.068 \mathrm{~kg} \cdot \mathrm{kg}^{-1}$. It was significantly higher (by $0.032 \mathrm{~kg} \cdot \mathrm{kg}^{-1}$ ) in August than in June. In comparison with the control plots, a significant rise in the field water capacity (at the potential of $-15.5 \mathrm{kPa}$ ) by $0.012 \mathrm{~kg} \cdot \mathrm{kg}^{-1}$ was observed only in the plots with the doses of $2 \mathrm{~g} \cdot \mathrm{kg}^{-1}$ (Tab. 1). No significant differences were found in the water capacity at the potential of $155.4 \mathrm{kPa}$ resulted from the addition of AgroHydroGel. The soil moisture at permanent wilting of plants $(-1554 \mathrm{kPa})$ increased significantly by $0.007 \mathrm{~kg} \cdot \mathrm{kg}^{-1}$ at the hydrogel dose of $2 \mathrm{~g} \cdot \mathrm{kg}^{-1}$.

The retention of water useful to plants (in the range of the water potential from -15.5 to $-1554 \mathrm{kPa}$ ) showed no significant change after the application of AgroHydroGel. However, it was significantly higher (by $0.014 \mathrm{~kg} \cdot \mathrm{kg}^{-1}$ ) in August than in June (Tab. 2). There were no differences in the retention of easily available water (from -15.5 to $-155.4 \mathrm{kPa}$ ) among the plots, whereas the retention of poorly available water (from $-155.4 \mathrm{kPa}$ to $-1554 \mathrm{kPa}$ ) decreased by $0.005-0.006$ $\mathrm{kg} \cdot \mathrm{kg}^{-1}$ under the influence of the gel-forming polymer. The saturated hydraulic 
TABLE 1. Bulk density and water capacity in Ap horizons (mean values in 3 soils)

\begin{tabular}{|c|c|c|c|c|c|c|c|}
\hline \multirow{2}{*}{$\begin{array}{l}\text { Time } \\
\text { of sampling (T) }\end{array}$} & \multirow{2}{*}{$\begin{array}{c}\text { Dose of } \\
\text { AgroHydroGel } \\
\left(\mathrm{g} \cdot \mathrm{kg}^{-1}\right)(\mathrm{D})\end{array}$} & \multirow{2}{*}{$\begin{array}{c}\text { Bulk } \\
\text { density } \\
\left(\mathrm{Mg} \cdot \mathrm{m}^{-3}\right)\end{array}$} & \multirow{2}{*}{$\begin{array}{l}\text { Actual } \\
\text { moisture } \\
\left(\mathrm{kg} \cdot \mathrm{kg}^{-1}\right)\end{array}$} & \multicolumn{4}{|c|}{ Water content $\left(\mathrm{kg} \cdot \mathrm{kg}^{-1}\right)$ at } \\
\hline & & & & $\begin{array}{c}-0.1 \\
\mathrm{kPa}\end{array}$ & $\begin{array}{c}-15.5 \\
\mathrm{kPa}\end{array}$ & $\begin{array}{c}-155.4 \\
\mathrm{kPa}\end{array}$ & $\begin{array}{c}-1554 \\
\mathrm{kPa}\end{array}$ \\
\hline \multirow[t]{4}{*}{14 June 2005} & 0 & 1.31 & 0.184 & 0.389 & 0.262 & 0.122 & 0.069 \\
\hline & 1 & 1.31 & 0.176 & 0.388 & 0.265 & 0.118 & 0.071 \\
\hline & 2 & 1.20 & 0.174 & 0.457 & 0.271 & 0.121 & 0.077 \\
\hline & mean & 1.27 & 0.178 & 0.411 & 0.266 & 0.120 & 0.072 \\
\hline \multirow[t]{4}{*}{8 August 2005} & 0 & 1.31 & 0.134 & 0.387 & 0.273 & 0.123 & 0.069 \\
\hline & 1 & 1.16 & 0.145 & 0.487 & 0.275 & 0.120 & 0.071 \\
\hline & 2 & 1.20 & 0.147 & 0.455 & 0.286 & 0.124 & 0.075 \\
\hline & mean & 1.22 & 0.142 & 0.443 & 0.278 & 0.122 & 0.071 \\
\hline \multirow[t]{4}{*}{ Two time mean } & 0 & 1.31 & 0.159 & 0.388 & 0.267 & 0.122 & 0.069 \\
\hline & 1 & 1.23 & 0.160 & 0.438 & 0.270 & 0.119 & 0.071 \\
\hline & 2 & 1.20 & 0.160 & 0.456 & 0.279 & 0.123 & 0.076 \\
\hline & mean & 1.25 & 0.160 & 0.427 & 0.272 & 0,121 & 0.072 \\
\hline \multirow[t]{3}{*}{$\operatorname{LSD}(\alpha=0.05)$} & for doses D & 0.04 & n. s. & 0.026 & 0.009 & n. s. & 0.004 \\
\hline & for times $\mathrm{T}$ & 0.03 & 0.006 & 0.018 & 0.006 & n. s. & n. s. \\
\hline & interaction $\mathrm{D} \cdot \mathrm{T}$ & 0.06 & 0.013 & 0.037 & n. s. & n. s. & n. s. \\
\hline
\end{tabular}

n. s. - non-significant differences.

TABLE 2. Water retention and saturated hydraulic conductivity in Ap horizons (mean values in 3 soils)

\begin{tabular}{|c|c|c|c|c|c|}
\hline \multirow[b]{2}{*}{$\begin{array}{l}\text { Time } \\
\text { of sampling }(\mathrm{T})\end{array}$} & \multirow[b]{2}{*}{$\begin{array}{c}\text { Dose of } \\
\text { AgroHydroGel } \\
\left(\mathrm{g} \cdot \mathrm{kg}^{-1}\right)(\mathrm{D})\end{array}$} & \multicolumn{3}{|c|}{ Retention of water $\left(\mathrm{kg} \cdot \mathrm{kg}^{-1}\right)$} & \multirow{2}{*}{$\begin{array}{c}\text { Saturated } \\
\text { hydraulic } \\
\text { conductivity } \\
\left(\mathrm{m} \cdot \mathrm{d}^{-1}\right)\end{array}$} \\
\hline & & $\begin{array}{c}\text { useful } \\
\text { for plants }\end{array}$ & $\begin{array}{c}\text { easily } \\
\text { available } \\
\text { for plants }\end{array}$ & $\begin{array}{c}\text { poorly } \\
\text { available } \\
\text { for plants }\end{array}$ & \\
\hline \multirow[t]{4}{*}{14 June 2005} & 0 & 0.193 & 0.140 & 0.053 & 2.00 \\
\hline & 1 & 0.194 & 0.147 & 0.047 & 2.05 \\
\hline & 2 & 0.193 & 0.150 & 0.043 & 4.62 \\
\hline & mean & 0.193 & 0.146 & 0.048 & 2.89 \\
\hline \multirow[t]{4}{*}{8 August 2005} & 0 & 0.204 & 0.151 & 0.053 & 1.40 \\
\hline & 1 & 0.204 & 0.154 & 0.050 & 5.61 \\
\hline & 2 & 0.212 & 0.162 & 0.050 & 5.83 \\
\hline & mean & 0.207 & 0.156 & 0.051 & 4.28 \\
\hline \multirow[t]{4}{*}{ Two time mean } & 0 & 0.199 & 0.145 & 0.053 & 1.70 \\
\hline & 1 & 0.199 & 0.151 & 0.048 & 3.83 \\
\hline & 2 & 0.203 & 0.156 & 0.047 & 5.22 \\
\hline & mean & 0.200 & 0.151 & 0.049 & 3.58 \\
\hline \multirow[t]{3}{*}{$\operatorname{LSD}(\alpha=0.05)$} & for doses $\mathrm{D}$ & n. s. & n. s. & 0.004 & 0.90 \\
\hline & for times $T$ & 0.006 & 0.007 & 0.002 & 0.61 \\
\hline & interaction $\mathrm{D} \cdot \mathrm{T}$ & n. s. & n. s. & n. s. & 1.28 \\
\hline
\end{tabular}

n. s. - non-significant differences. 
conductivity in the soil surface layer showed a significant increase by $2.13 \mathrm{~m} \cdot \mathrm{d}^{-1}$ in the plots with the dose of $1 \mathrm{~g} \cdot \mathrm{kg}^{-1}$ and by $3.52 \mathrm{~m} \cdot \mathrm{d}^{-1}$ in the plots with the dose of $2 \mathrm{~g} \cdot \mathrm{kg}^{-1}$.

The total porosity in the soils improved by AgroHydroGel was significantly greater by $0.028-0.040 \mathrm{~m}^{3} \cdot \mathrm{m}^{-3}$ while compared with control plots (Tab. 3). It was significantly higher by $0.019 \mathrm{~m}^{3} \cdot \mathrm{m}^{-3}$ in August than in June. The addition of the polymer increased significantly the content of macropores with the diameter equivalent to $>20 \mu \mathrm{m}$ by $0.045 \mathrm{~m}^{3} \cdot \mathrm{m}^{-3}$ in the plots with the dose of $1 \mathrm{~g} \cdot \mathrm{kg}^{-1}$ and by $0.054 \mathrm{~m}^{3} \cdot \mathrm{m}^{-3}$ in the plots with the dose of $2 \mathrm{~g} \cdot \mathrm{kg}^{-1}$. By contrast, the content of mesopores with the diameters ranged from 0.2 to $20 \mu \mathrm{m}$ in the soils with the addition of hydrogel fell significantly by $0.015 \mathrm{~m}^{3} \cdot \mathrm{m}^{-3}$ in comparison with the control. As regards the content of micropores with the diameter $<0.2 \mu \mathrm{m}$, there were only insignificant differences among the plots.

In comparison with the not improved soils, actual air permeability increased significantly in the soils treated with AgroHydroGel (by $91.9 \cdot 10^{-8} \mathrm{~m}^{2} \cdot \mathrm{Pa}^{-1} \cdot \mathrm{s}^{-1}$ in the plots with the dose of $1 \mathrm{~g} \cdot \mathrm{kg}^{-1}$ and by $79.9 \cdot 10^{-8} \mathrm{~m}^{2} \cdot \mathrm{Pa}^{-1} \cdot \mathrm{s}^{-1}$ in the plots with the dose of $\left.2 \mathrm{~g} \cdot \mathrm{kg}^{-1}\right)$. Similarly, the air permeability at field water capacity was significantly higher (at $-15.5 \mathrm{kPa}$ ), by $86.9 \cdot 10^{-8} \mathrm{~m}^{2} \cdot \mathrm{Pa}^{-1} \cdot \mathrm{s}^{-1}$ in the plots with the dose of $1 \mathrm{~g} \cdot \mathrm{kg}^{-1}$ and by $94.0 \cdot 10^{-8} \mathrm{~m}^{2} \cdot \mathrm{Pa}^{-1}$. $\cdot \mathrm{s}^{-1}$ in the plots with the dose of $2 \mathrm{~g} \cdot \mathrm{kg}^{-1}$ (Tab. 3).

This study showed that AgroHydroGel applied in small doses improved the majority of water-air properties in the surface layer of the eroded Haplic Luvisols developed from loess. Its use had a beneficial effect on a decrease in bulk

TABLE 3. Porosity and air permeability in Ap horizons (mean values in 3 soils)

\begin{tabular}{|c|c|c|c|c|c|c|c|}
\hline \multirow{2}{*}{$\begin{array}{l}\text { Time } \\
\text { of sampling }(\mathrm{T})\end{array}$} & \multirow{2}{*}{$\begin{array}{c}\text { Dose of } \\
\text { AgroHydroGel } \\
\left(\mathrm{g} \cdot \mathrm{kg}^{-1}\right)(\mathrm{D})\end{array}$} & \multirow{2}{*}{$\begin{array}{c}\text { Total } \\
\text { porosity } \\
\left(\mathrm{m}^{3} \cdot \mathrm{m}^{-3}\right)\end{array}$} & \multicolumn{3}{|c|}{$\begin{array}{l}\text { Pore-size content } \\
\qquad\left(\mathrm{m}^{3} \cdot \mathrm{m}^{-3}\right)\end{array}$} & \multicolumn{2}{|c|}{$\begin{array}{l}\text { Air permeability } \\
\left(\cdot 10^{-8} \mathrm{~m}^{2} \cdot \mathrm{Pa}^{-1} \cdot \mathrm{s}^{-1}\right)\end{array}$} \\
\hline & & & $\begin{array}{l}>20 \\
\mu \mathrm{m}\end{array}$ & $\begin{array}{c}0.2-20 \\
\mu \mathrm{m}\end{array}$ & $\begin{array}{c}<0.2 \\
\mu \mathrm{m}\end{array}$ & actual & at $-15.5 \mathrm{kPa}$ \\
\hline \multirow[t]{4}{*}{14 June 2005} & 0 & 0.506 & 0.165 & 0.252 & 0.089 & 61.8 & 23.8 \\
\hline & 1 & 0.505 & 0.159 & 0.253 & 0.093 & 60.8 & 23.3 \\
\hline & 2 & 0.546 & 0.221 & 0.232 & 0.093 & 101.8 & 52.8 \\
\hline & mean & 0.519 & 0.182 & 0.246 & 0.092 & 74.8 & 33.3 \\
\hline \multirow[t]{4}{*}{8 August 2005} & 0 & 0.505 & 0.148 & 0.267 & 0.091 & 49.7 & 18.9 \\
\hline & 1 & 0.562 & 0.245 & 0.236 & 0.082 & 234.6 & 193.1 \\
\hline & 2 & 0.545 & 0.201 & 0.255 & 0.089 & 169.5 & 177.7 \\
\hline & mean & 0.538 & 0.198 & 0.252 & 0.087 & 151.3 & 129.9 \\
\hline \multirow[t]{4}{*}{ Two time mean } & 0 & 0.506 & 0.157 & 0.259 & 0.090 & 55.8 & 21.3 \\
\hline & 1 & 0.534 & 0.202 & 0.244 & 0.087 & 147.7 & 108.2 \\
\hline & 2 & 0.546 & 0.211 & 0.244 & 0.091 & 135.7 & 115.3 \\
\hline & mean & 0.529 & 0.190 & 0.249 & 0.089 & 113.0 & 81.6 \\
\hline \multirow[t]{3}{*}{$\operatorname{LSD}(\alpha=0.05)$} & for doses D & 0.015 & 0.024 & 0.012 & n. s. & 71.8 & 55.5 \\
\hline & for times $\mathrm{T}$ & 0.010 & 0.016 & n. s. & 0.003 & 48.8 & 37.7 \\
\hline & interaction $\mathrm{D} \cdot \mathrm{T}$ & 0.021 & 0.033 & 0.017 & 0.007 & 101.6 & 78.4 \\
\hline
\end{tabular}

n. s. - non-significant differences. 
density and, simultaneously, the hydrogel increased significantly the maximum water capacity, saturatedhydraulic conductivity, total porosity, content of micropores $>20 \mu \mathrm{m}$, actual air permeability and air permeability at field water saturation. A significant decrease in the number of mesopores with a size of $0.2-20 \mu \mathrm{m}$ was a less positive effect, though. The dose of $2 \mathrm{~g} \cdot \mathrm{kg}^{-1}$ of hydrogel proved to be more effective than the dose of $1 \mathrm{~g} \cdot \mathrm{kg}^{-1}$, enhancing significantly field water capacity. However, this dose contributed to higher soil moisture at permanent wilting of plants which resulted from strong sorption of water by molecular forces of macronets. Consequently, the absorbed water was partly immobilised in the gel as unavailable for plants. Other research conducted by the authors simultaneously showed a positive influence of AgroHydroGel applied in doses of $1 \mathrm{~g} \cdot \mathrm{kg}^{-1}$ and $2 \mathrm{~g} \cdot \mathrm{kg}^{-1}$ on the aggregate structure of eroded Haplic Luvisols developed from loess (Paluszek and Żembrowski 2008). The hydrogel amended the aggregate size distribution in the $0-5 \mathrm{~cm}$ layer of Ap horizon by a significant decrease of the share of clods $>10 \mathrm{~mm}$ and an increase of the content of water-stable aggregates with a size of $0.25-5 \mathrm{~mm}$ and $0.25-10 \mathrm{~mm}$.

The doses of AgroHydroGel applied in the present experiment turned out to be too small to enhance significantly actual soil moisture and retention of water useful to plants, including retention of easily available water.

Studies elsewhere show that the influence of AgroHydroGel on water and air properties of soils proved to be not as great in comparison with the effectiveness of other gel-forming polymers (Paluszek
2003; Akhter et al. 2004; De Oliveira et al. 2004; Sivapalan 2006). The application of Viterra (a potassium propenoatepropenamide copolymer) in the doses of 0.5 and $1 \mathrm{~g} \cdot \mathrm{kg}^{-1}$ resulted in a significant decrease in the bulk density and significant increases in the maximum and field water capacity, retention of useful water, total porosity and content of air pores in eroded Haplic Luvisols developed from loess (Paluszek 2003). Akhter et al. (2004) enriched the loam and sandy loam soils with a gel-forming polyacrylamide in the doses of 1,2 and $3 \mathrm{~g} \cdot \mathrm{kg}^{-1}$. The authors observed a rise both in the field water capacity and retention of water useful to plants proportional to the hydrogel dose, and a significant fall in the soil moisture at permanent wilting of plants in the enriched soils compared to the control. De Oliveira et al. (2004) also stated a significant increase in water capacity in the range of the soil water potential from $-0.1 \mathrm{kPa}$ to $-1000 \mathrm{kPa}$ in the loamy and clayey soils after the application of TerraCottem hydrogel in the doses of $0.1 \mathrm{~g} \cdot \mathrm{kg}^{-1}$ to $2 \mathrm{~g} \cdot \mathrm{kg}^{-1}$. The dose of $2 \mathrm{~g} \cdot \mathrm{kg}^{-1}$ enhanced the water capacity at the potential $-30 \mathrm{kPa}$ by $41 \%$ and $37 \%$ and retention of water useful to plants by $23 \%$ and $35 \%$ respectively. Sivapalan (2006) noted an increase of the water capacity in the range of potential from $-10 \mathrm{kPa}$ to $-1550 \mathrm{kPa}$ in the sandy soil amended by a gel-forming polyacrylamide (Alcosorb 400) applied in the doses of $0.3 \mathrm{~g} \cdot \mathrm{kg}^{-1}$ and $0.7 \mathrm{~g} \cdot \mathrm{kg}^{-1}$. The water capacity at $-10 \mathrm{kPa}$ was higher by $23 \%$ and $95 \%$ respectively. Since the soil moisture at permanent wilting of plants also increased, the retention of water useful to plants treated with Alcosorb was only slightly higher, though. In the study by 
Geesing and Schmidhalter (2004) conducted on the loam, sandy loam and silty-clay loam soils, the use of sodium polyacrylate contributed to a significant rise in the retention of water useful for plants at the doses of 3 and $5 \mathrm{~g} \cdot \mathrm{dm}^{-3}$ while no significant influence of the dose of $1 \mathrm{~g} \cdot \mathrm{dm}^{-3}$ was observed. Al-Darby (1996) reported that the application of Jalma hydrogel in the doses of 2,4 , and $8 \mathrm{~g} \cdot \mathrm{kg}^{-1}$ increased the water capacity in the range of potential from $0.1 \mathrm{kPa}$ to $-1554 \mathrm{kPa}$, proportionally to the dose. Whereas the water capacity at $-33 \mathrm{kPa}$ was found to be higher by $54 \%, 130 \%$ and $250 \%$, and retention of water useful for plants by $46 \%, 70 \%$ and $91 \%$, saturated hydraulic conductivity was reduced by $46 \%, 92 \%$ and $99 \%$ respectively.

During moisturizing amide functional groups in cross-linked chains undergo solvation and dissociate, univalent cations $\left(\mathrm{Na}^{+}, \mathrm{K}^{+}\right)$are released, and negative charges of a polymer chain repel each other under the influence of Coulomb forces, which is typical behaviour of gel-forming polymers in soil (Bereś and Kałędkowska 1992; Singh 1997). This results in slow opening of coiled macronets which gain the ability to absorb water further and to form gel. The strongly swollen gel absorbs water until polymer chains forming a space lattice elongate to a maximum. Hydrogel swelling during moisturizing causes soil loosening and therefore bulk density decreases whereas total porosity increases, including particularly the share of macropores which determines hydraulic conductivity and air permeability.

Lower effectiveness of AgroHydroGel, as compared to Viterra, Alcosorb and TerraCottem spread over in similar or smaller doses, may be explained by a different chemical composition and higher density of macronet cross-linking which results in their lower water absorption ability (Hua and Qian 2001). Dissimilarities in acting of gel-forming polymers may be also caused by different textures of soils and their physical, physico-chemical and chemical properties. An optimal dose of hydrogel is of great importance for the efficiency and cost-effectiveness of treatment. The introduction of higher doses, above the optimum level for a given polymer, may increase retention of water unavailable for plants.

\section{CONCLUSIONS}

- AgroHydroGel applied in the doses of 1 and $2 \mathrm{~g} \cdot \mathrm{kg}^{-1}$ improved effectively the majority of water-air properties in the 0-5 cm layer of eroded Haplic Luvisols developed from loess. The addition of the polymer significantly decreased the bulk density and increased the maximum water capacity, saturated hydraulic conductivity, total porosity, content of macropores $>20 \mu \mathrm{m}$, actual air permeability and air permeability at field water saturation. Simultaneously, the content of soil mezopores with the diameter of $0.2-20 \mu \mathrm{m}$ was reduced.

- The dose of $2 \mathrm{~g} \cdot \mathrm{kg}^{-1}$ of AgroHydroGel had a greater effect, increasing significantly the field water capacity but also the wilting point moisture in the soils studied.

- No significant differences were stated in the actual soil moisture, retention of water useful for plants, including retention of easy available water, and the content of micropores $<0.2 \mu \mathrm{m}$ at the applied doses of hydrogel. 
- The influence of AgroHydroGel on water-air properties of the eroded soils was greater in August than in June.

- In consideration of high costs of AgroHydroGel the application of this polymer in agricultural practice is unprofitable.

\section{REFERENCES}

AKHTER J., MAHMOOD K., MALIK K.A., MARDAN A., AHMAD M., IQBAL M.M. 2004: Effects of hydrogel amendment on water storage of sandy loam and loam soils and seedling growth of barley, wheat and chickpea. Plant Soil Environ. 50, 463-469.

AL-DARBY A.M. 1996: The hydraulic properties of a sandy soil treated with gel-forming soil conditioner. Soil Technol. 9, 15-28.

ARRIAGA F.J., LOWERY B. 2003: Soil physical properties and crop productivity of an eroded soil amended with cattle manure. Soil Sci. 168, 888-899.

BEREŚ J., KAŁĘDKOWSKA M. 1992: Superabsorbenty [Superabsorbents]. Chemik 45, 3, 59-61 [Engl. summ.].

DABNEY S.M., DELGADO J.A., REEVES D.W. 2001: Using winter cover crops to improve soil and water quality. Commun. Soil Sci. Plant Anal. 32, 1221-1250.

DE OLIVEIRA R.A., REZENDE L.S., MARTINEZ M.A., MIRANDA G.V. 2004: Effect of a hydrogel polymer on the soil water retention. Revista Bras. Eng. Agricola e Ambiental 8, 1, 160-163.

EBEID M.M., LAL R., HALL G.F., MILLER E. 1995: Erosion effects on soil properties and soybean yield of a Miamian soil in Western Ohio in a season with below normal rainfall. Soil Technol. 8, 97-108.

GEESING D., SCHMIDHALTER U. 2004: Influence of sodium polyacrylate on the water-holding capacity of three different soils and effects on growth of wheat. Soil Use Manag. 20, 207-209.

HUA F., QIAN M. 2001: Synthesis of self-crosslinking sodium polyacrylate hydrogel and water absorbing mechanism. J. Materials Sci. 36, 731-738.
HUSSAIN I., OLSON K.R., SIEMENS J.C. 1998: Long-term tillage effects on physical properties of eroded soil. Soil Sci. 163, 970-981.

LAL R. 1998: Soil erosion impact on agronomic productivity and environment quality. Critical Rev.Plant Sci. 15, 319-464.

LOWERY B., SWAN J., SCHUMACHER T., JONES A. 1995: Physical properties of selected soils by erosion class. J. Soil Water Conserv. 50, 306-311.

PALUSZEK J. 2003: Kształtowanie syntetycznymi polimerami właściwości gleb erodowanych terenów lessowych [Formation of soil properties of eroded loessial terrains by the synthetic polymers]. Rozpr. Nauk. AR w Lublinie 277, 1-153 [Engl. summ.].

PALUSZEK J., ŻEMBROWSKI W. 2008: Ocena przydatności polimeru AgroHydroGel do ulepszania struktury erodowanych gleb lessowych [Evaluation of suitability of AgroHydroGel polymer for improvement of soil structure of eroded loessial soils]. Rocz. Glebozn. 59, 1/2 (in print) [Engl. summ.].

SHUKLA M.K., LAL R. 2005: Erosional effects on soil physical properties in an on-farm study on Alfisols in West Central Ohio. Soil Sci. 170, 445-456.

SINGH J. 1997: Physical behavior of superabsorbent hydrogels in sand. Phil. Dr. Thesis, McGill Univ., Montreal, $115 \mathrm{p}$.

SIVAPALAN S. 2006: Benefits of treating a sandy soil with a crosslinked-type polyacrylamide. Aust. J. Exp. Agr. 46, 579-584.

Streszczenie: Ulepszanie wodno-powietrznych wlaściwości erodowanych gleb $w$ krajobrazie lessowym za pomoca agrohydrogelu. Badania prowadzono $\mathrm{w}$ poletkowym doświadczeniu na zerodowanych glebach płowych wytworzonych $\mathrm{z}$ lessu w gospodarstwie indywidualnym w Bogucinie $\left(51^{\circ} 20^{\prime} \mathrm{N}, 22^{\circ} 23^{\prime} \mathrm{E}\right)$ na Wyżynie Lubelskiej. Po siewie pszenicy jarej na badanych glebach wytyczono 9 poletek o powierzchni $9 \mathrm{~m}^{2}$, w tym trzy poletka kontrolne. AgroHydroGel wysiano w dawkach $1 \mathrm{~g} \cdot \mathrm{kg}^{-1}$ i $2 \mathrm{~g} \cdot \mathrm{kg}^{-1} \mathrm{w}$ stosunku do masy gleby suchej $\mathrm{w}$ warstwie $0-5 \mathrm{~cm}$ i wymieszano z gleba. AgroHydroGel jest usieciowanym, hydrofilowym kopolimerem poliakryloamidowym, o absorpcji wody $300-500 \mathrm{~g} \cdot \mathrm{cm}^{-3}$. Próbki glebowe pobrano w czerwcu i sierpniu 2005 r. z warstwy 0-5 cm. Wyniki badań wykazały, że wniesienie 
AgroHydroGelu w dawkach 1 i $2 \mathrm{~g} \cdot \mathrm{kg}^{-1}$ polepszyło większość właściwości wodno-powietrznych w warstwie $0-5 \mathrm{~cm}$ gleb. Zmniejszyła się istotnie gęstość gleby, zwiększyła się istotnie pełna pojemność wodna, przewodnictwo wodne nasycone, porowatość ogólna, zawartość makroporów $>20 \mu \mathrm{m}$ oraz aktualna przepuszczalność powietrzna i przepuszczalność przy polowym nasyceniu woda. Skuteczniej działała dawka polimeru $2 \mathrm{~g} \cdot \mathrm{kg}^{-1}$, która zwiększyła istotnie również polową pojemność wodną w badanych glebach. Zastosowane dawki hydrożelu nie zmieniły istotnie wilgotności aktualnej gleb, retencji wody użytecznej dla roślin, w tym retencji wody łatwo dostępnej oraz zawartości mikroporów glebowych o średnicy $<0,2 \mu \mathrm{m}$. Bardziej korzystny wpływ AgroHydroGelu na właściwości wodno-powietrzne gleb zerodowanych stwierdzono w sierpniu.

MS. received May 10, 2008

Authors' address:

Instytut Gleboznawstwa i Kształtowania

Środowiska

Uniwersytet Przyrodniczy w Lublinie ul. S. Leszczyńskiego 7, 20-069 Lublin Poland

e-mail: jan.paluszek@ar.lublin.pl 